\title{
Mechanisms involved in exogenous C2- and C6-ceramide-induced cancer cell toxicity
}

\author{
Marianne Fillet ${ }^{\mathrm{a},{ }^{*}}$, Mohamed Bentires-Alj ${ }^{\mathrm{a}}$, Valerie Deregowski ${ }^{\mathrm{a}}$, Roland Greimers ${ }^{\mathrm{b}}$, \\ Jacques Gielen ${ }^{\mathrm{a}}$, Jacques Piette ${ }^{\mathrm{c}}$, Vincent Bours ${ }^{\mathrm{a}}$, Marie-Paule Merville ${ }^{\mathrm{a}}$ \\ ${ }^{\mathrm{a}}$ Laboratory of Clinical Chemistry and Human Genetics, CHU B35, University of Liège, Sart-Tilman, 4000 Liège, Belgium \\ ${ }^{\mathrm{b}}$ Laboratory of Pathological Anatomy, University of Liège, Liège, Belgium \\ ${ }^{c}$ Laboratory of Fundamental Virology, Center for Cellular and Molecular Therapy, University of Liège, Liège, Belgium
}

Received 12 April 2002; accepted 20 November 2002

\begin{abstract}
Ceramides are important intracellular second messengers that play a role in the regulation of cell growth, differentiation, and programmed cell death. To determine whether ceramides can mediate the apoptosis of HCT116 and OVCAR-3 cancer cells, exogenous C2-, C6-, and C16-ceramides were used to mimic the endogenous lipid increase that follows a large variety of stresses. C2- and C6ceramides (cell-permeable ceramide analogs), but not C16-ceramide, induced nuclear factor- $\kappa \mathrm{B}$ (NF- $\kappa \mathrm{B}) \mathrm{DNA}-\mathrm{binding}$, caspase-3 activation, poly(ADP-ribose) polymerase degradation, and mitochondrial cytochrome $c$ release, indicating that apoptosis occurs through the caspase cascade and the mitochondrial pathway. No difference in survival was observed between control cells and cells expressing

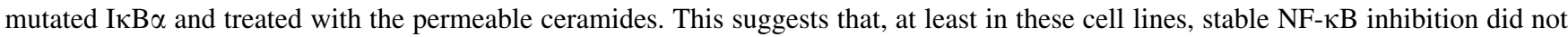
modify the ceramide-induced cytotoxicity pathway. C6-ceramide also induced a double block in G1 and G2, thus emptying the S phase. (C) 2003 Elsevier Science Inc. All rights reserved.
\end{abstract}

Keywords: Ceramide; Caspase; NF-кB; Apoptosis; Cancer cells

\section{Introduction}

The sphingomyelin pathway is a ubiquitous signaling system that links specific cell-surface receptors and different types of physical stress to the nucleus [1-3]. This pathway is initiated by the hydrolysis of membrane phospholipid sphingomyelin to ceramide, which results from the activation of sphingomyelin-specific forms of phospholipase $\mathrm{C}$ called sphingomyelinases. Ceramides are also generated by another mechanism involving ceramide synthase. Structurally, the ceramides exhibit a long amino alcoholic chain covalently bound via an amide linkage to a fatty acyl moiety that can vary in length (synthetic short chain ceramides: C2-, C4-, C6-, ... or natural ceramides: C16-, C18-, C20-, ...) [4].

\footnotetext{
${ }^{*}$ Corresponding author. Tel.: +32-4-3664354; fax: +32-4-3664347.

E-mail address: marianne.fillet@ulg.ac.be (M. Fillet).

Abbreviations: DAPI, 4',6-diamidine-2'-phenylindole dihydrochloride; EMSA, electrophoretic mobility shift assay; NF- $\kappa \mathrm{B}$, nuclear factor- $\kappa \mathrm{B}$; PARP, poly(ADP-ribose) polymerase; and TNF- $\alpha$, tumor necrosis factor- $\alpha$.
}

Ceramides are produced in response to a large variety of stresses that mediate growth arrest, differentiation, senescence, apoptosis, or immune response [5,6]. The wide range of biological effects mediated by ceramides depends on many parameters, such as the cell type, the nature of the cell receptors expressed, and their concentration, suggesting the existence of multiple downstream targets activated through distinct intracellular pathways.

One of the most clearly illustrated targets of ceramides is cell death [7-15]. Interestingly, ceramides induce not only apoptosis, but also caspase-independent and/or non-apoptotic cell death, depending on the cell type. Recent data demonstrate that ceramides play an important role in one or several stages of apoptosis. Indeed, several cytokines and environment stresses known to initiate apoptosis, including TNF- $\alpha$, CD95/Fas/APO-1, chemotherapeutic drugs, ionizing radiations, ultraviolet radiation, heat shock, and oxidative stress, appear to induce a rapid rise of intracellular ceramide concentration $[9,11,15-17]$.

The mechanism by which ceramides mediate apoptosis has not been fully addressed yet, although mitochondria 
are known to be a target for ceramides. Recent studies have demonstrated that exogenous ceramides can induce the alteration of mitochondrial calcium homeostasis [18]. Moreover, C2-ceramide has been reported to increase the permeability of mitochondrial membranes and to decrease the membrane potential [19]. Ceramides also mediate apoptosis in HL-60 cells through mitochondrial signaling, which involves translocation of Bax to mitochondria where it promotes the release of cytochrome $c$ [20].

However, it is still unknown whether ceramides are essential for the initiation or for the execution of apoptosis $[7,12,21]$. The clarification of the role of ceramides in apoptosis may provide further insights into the treatment of several human diseases, such as cancer. Indeed, recent reports have shown that ceramide-dependent stress signaling is associated with chemotherapeutic agents known to trigger apoptosis. It is not entirely clear, however, what step of the transduction pathway leading to apoptosis is influenced or dependent upon ceramide generation $[8,22]$.

It has been reported that the addition of exogenous sphingomyelinase or ceramide induces NF- $\kappa \mathrm{B}$ activation [23]. NF- $\kappa \mathrm{B}$ is a rapidly inducible transcription factor, activated by a number of external or internal stimuli, such as cytokines, chemotherapeutic agents, or radiation. NF-кB can protect several cell types against apoptosis, suggesting that it can participate in resistance to cancer treatment. However, in our experience, the inhibition of NF- $\kappa \mathrm{B}$ activity in several cancer cell lines has a variable effect on cell mortality, depending on the cell type, the stimulus, and the level of NF- $\mathrm{KB}$ inhibition (for a review, see Ref. [24]). Moreover, in some experimental systems, NF- $\mathrm{KB}$ activation is required for the onset of apoptosis [25].

Ceramides have also been shown to play a role in growth arrest at the G0/G1 phase of the cell cycle in response to serum withdrawal. For instance, Molt-4 leukaemia cells treated with C6-ceramide undergo a G0/G1 cell cycle arrest [26].

In the present study, we demonstrated that the $\mathrm{C} 2$ - and C6-ceramides induce NF- $\kappa \mathrm{B}$ activation, caspase-3 activity, PARP cleavage, and mitochondrial cytochrome $c$ release in human colon carcinoma cells (HCT116) and in ovarian carcinoma cells (OVCAR-3). Exogenous C16-ceramide, which likely does not penetrate into the cell, had no effect. These results suggest that permeable ceramide-induced apoptosis involves mitochondria effectors and caspase activity. In addition, the role of ceramide in cell cycle arrest has been investigated.

\section{Materials and methods}

\subsection{Cell culture and biological reagents}

HCT116 human colon carcinoma cells (ATCC CCL 247) were cultured in McCoy's 5A modified medium (Life
Technologies, Inc.) supplemented with $10 \%$ fetal bovine serum, $1 \%$ L-glutamine $(200 \mathrm{mM}), 100$ units/mL of penicillin, and $100 \mu \mathrm{g} / \mathrm{mL}$ of streptomycin. OVCAR-3 ovarian carcinoma cells were maintained in RPMI 1640 medium (Life Technologies) supplemented with 10\% fetal bovine serum, $1 \%$ L-glutamine $(200 \mathrm{mM}), 100$ units $/ \mathrm{mL}$ of penicillin, and $100 \mu \mathrm{g} / \mathrm{mL}$ of streptomycin. The cells were maintained at $37^{\circ}$ in a $5 \% \mathrm{CO}_{2}$ atmosphere.

HCT116-MT and OVCAR-3-MT cells were stably transfected with an expressing vector coding for an I $\mathrm{\kappa B} \alpha$ protein mutated at serines 32 and 36 and cultivated in the presence of geneticin $(500 \mu \mathrm{g} / \mathrm{mL}, \mathrm{G} 418$ active concentration; Roche) [27].

C2-, C6-, and C16-ceramides were obtained from Sanver Tech (Boechout) and were solubilized in ethanol.

The human recombinant TNF- $\alpha$ (specific activity $>1.0 \times 10^{8}$ units $/ \mathrm{mg}$ ) was purchased from Roche. The caspase inhibitor Z-VAD-fmk and the caspase-3 inhibitor (Ac-DMQD-CHO) (Calbiochem) were added $1 \mathrm{hr}$ before treatment with ceramides.

\section{2. $E M S A$}

EMSA and supershifting analysis were performed as described previously [28]. The palindromic (PD) $-\kappa B$ probe was 5'-TTGGCAACGGCAGGGGAATTCCCCTCTCCTTAGGTT- $3^{\prime}$. For supershifting experiments, $1 \mu \mathrm{L}$ of the antibody was preincubated at $4^{\circ}$ with the extracts for $30 \mathrm{~min}$ before the addition of the labeled $\kappa \mathrm{B}$ probe. The antibody directed against an amino-terminal peptide of p50, the antibody directed against the $\mathrm{N}$-terminal 14 amino acids after the methionine of $\mathrm{p} 65$, and the p52 monoclonal antibody were purchased from Upstate Biotechnology. The anti-RelB and the c-Rel antibodies were purchased from Santa Cruz Biotechnology.

\subsection{Determination of cellular viability}

Stably transfected cells or untransfected cells were seeded at a concentration of $10^{4} /$ well in flat-bottomed 96-well plates in $0.2 \mathrm{~mL}$ of medium. After 24 or $48 \mathrm{hr}$ of incubation in the presence of ceramide, cell viability was measured by a colorimetric assay at $450 \mathrm{~nm}$, based on the cleavage of the tetrazolium salt WST-1 by mitochondrial dehydrogenases in viable cells (cell proliferation reagent WST-1; Roche).

\subsection{Protein extraction and western blot analysis}

Nuclear, cytoplasmic, and total protein extracts were prepared as previously described [29]. Protein amounts were quantified with the micro BCA Protein Assay Reagent kit (Pierce).

Analysis of PARP cleavage was assessed by western blot analysis. Briefly, extracts of $20 \mu \mathrm{g}$ of protein were run on $10 \%$ SDS-polyacrylamide gels, transferred, and incubated 
with an anti-PARP-specific monoclonal antibody (Santa Cruz Biotechnology) (1:5000), followed by a goat antimouse-specific antibody (1:5000), and developed using enhanced chemiluminescent detection methods (ECL Kit; Amersham Pharmacia Biotech). Analysis of caspase-3 was performed with an anti-caspase-3 monoclonal antibody (1/ 2000) (Alexis). Detection of caspase- 9 and cytochrome $c$ proteins was performed with an anti-caspase-9 polyclonal antibody (1/2000) and an anti-cytochrome $c$ monoclonal antibody (1/500) (Pharmigen), respectively.

\subsection{Caspase-3 activity assay}

Cells were washed two times with PBS, lysed at $4^{\circ}$ in buffer A (1\% Nonidet P-40, $20 \mathrm{mM}$ Tris, $137 \mathrm{mM} \mathrm{NaCl}$, $10 \%$ glycerol at $\mathrm{pH} 8$ ), in the presence of $1 \mathrm{mM}$ phenylmethylsulfonyl fluoride (PMSF), $1 \mathrm{mM}$ orthovanadate sodium, and protease inhibitors (Complete; Roche), and then centrifuged at $300 \mathrm{~g}$ for $5 \mathrm{~min}$ at $4^{\circ}$. Fifty micrograms of protein was incubated for $4 \mathrm{hr}$ in the dark with $150 \mu \mathrm{L}$ of buffer A containing a $20 \mathrm{mM}$ concentration of a caspase-3 substrate (acetyl-Asp-Glu-Val-Asp-amino-4-methylcoumarin; Calbiochem).

Caspase- 3 activity was determined by the amount of released fluorescent product (coumarin), measuring emission at $460 \mathrm{~nm}$ with $380 \mathrm{~nm}$ excitation.

\subsection{Flow cytometry analysis}

Cells were washed in PBS, harvested after trypsin treatment, and washed again in PBS. The pellets were stained with propidium iodide and fluorescein isothiocyanate (FITC)-conjugated Annexin V as described by the manufacturer (Annexin-V-FLUOS Staining Kit; Roche).

For cell cycle analysis, cells were prepared as described by the manufacturer (Cycle Test Plus DNA reagent kit; Becton Dickinson). A FACStar Plus flow cytometer (Becton Dickinson) with a $488 \mathrm{~nm}$ line $100 \mathrm{~mW}$ air-cooled argon laser (Spinnaker 1161; Spectra Physics) and Cell Quest software (Macintosh, Facstation; Becton Dickinson) were used for the analysis. DNA histograms were analyzed with ModFit software (Verity software).

\subsection{Preparation of cytosolic protein extracts}

To evaluate mitochondrial cytochrome $c$ release, cytosolic protein extracts were prepared. Briefly, cells were washed twice with PBS, and pellets were resuspended in ice-cold buffer containing $20 \mathrm{mM}$ HEPES, $\mathrm{pH}$ 7.5, $10 \mathrm{mM}$ $\mathrm{KCl}, 1.5 \mathrm{mM} \mathrm{MgCl}_{2}, 1 \mathrm{mM}$ sodium EDTA, $1 \mathrm{mM}$ sodium EGTA, $1 \mathrm{mM}$ dithiothreitol, and $1 \mathrm{mM}$ PMSF. Cells were disrupted by 12 runs through a Dounce homogenizer. Lysates were centrifuged at $10,000 \mathrm{~g}$ for $10 \mathrm{~min}$ and the resulting supernatants were further centrifuged at $100,000 \mathrm{~g}$ for $1 \mathrm{hr}$ at room temperature in a Beckman TLX ultracentrifuge (Beckman).

\subsection{Clonogenic survival assay}

Cells were seeded in six-well plates at a concentration of $30,000 /$ well and were treated with ceramide at different concentrations $(10,25$, and $50 \mu \mathrm{M})$ for 24 and $48 \mathrm{hr}$. Cells were then washed and incubated with fresh medium for 12 days. The number of colonies $(\geq 50$ cells) was counted after staining with crystal violet $(1 \%, \mathrm{v} / \mathrm{v})$.

\subsection{Determination of apoptosis by cytochemical staining}

The presence of apoptotic cells was determined by fluorescent microscopy. Cells were fixed with paraformaldehyde, incubated for $15 \mathrm{~min}$ with DAPI, and then visualized under fluorescent microscopy measuring emission at $460 \mathrm{~nm}$ with $360 \mathrm{~nm}$ excitation. The percentage of DAPIstained cells with apoptotic morphology (nuclear and cytoplasmic condensation, nuclear fragmentation, membrane blebbing, and apoptotic body formation) was evaluated by examining more than 400 cells/dish.

The presence of apoptotic cells was also examined by a TUNEL reaction, which preferentially labels DNA strand breaks generated during apoptosis (In Situ Cell Death Detection Kit, Fluorescein; Roche).

\subsection{Statistics}

Data are the means $\pm \mathrm{SD}$ of at least two independent experiments done in triplicate. Statistical significance was estimated with Student's $t$-test. A $P$ value of $<0.05$ was considered significant.

\section{Results}

\section{1. $N F-\kappa B$ activation by $C 2-$ and C6- but not by C16-ceramides}

The tumor cell lines HCT116 (human colorectal adenocarcinoma) and OVCAR-3 (human ovarian carcinoma) were stably transfected with a plasmid encoding a mutated, non-inducible I $\mathrm{I} \mathrm{B} \alpha$ inhibitor. We and others previously reported that such an $I \kappa B \alpha$ mutant can completely abolish $\mathrm{NF}-\kappa \mathrm{B}$ activation by a number of stimulating agents, such as TNF- $\alpha$ and anticancer drugs [27,29,30]. Indeed, after TNF- $\alpha$ stimulation, we confirmed by EMSA that NF- $\kappa B$ DNA-binding activity was strongly induced in control cells but was inhibited markedly in mutated IкB $\alpha$ transfected cells (data not shown).

HCT116 and OVCAR-3 control and transfected cells were treated with three different ceramides (C2-, C6-, and C16-ceramides) at $50 \mu \mathrm{M}$, and NF- $\kappa \mathrm{B}$ DNA-binding activity was analyzed at different times after the treatment $(1,2$, 4,6 , and $24 \mathrm{hr}$ ).

$\mathrm{C} 2$ - and C6-ceramides induced NF- $\mathrm{KB}$ nuclear translocation in OVCAR-3 cells (Fig. 1A and B) and in HCT116 


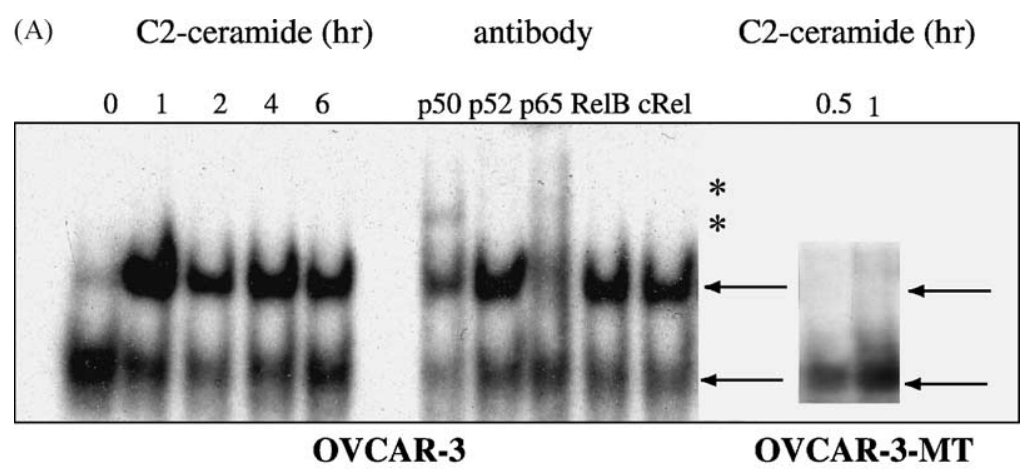

(B)

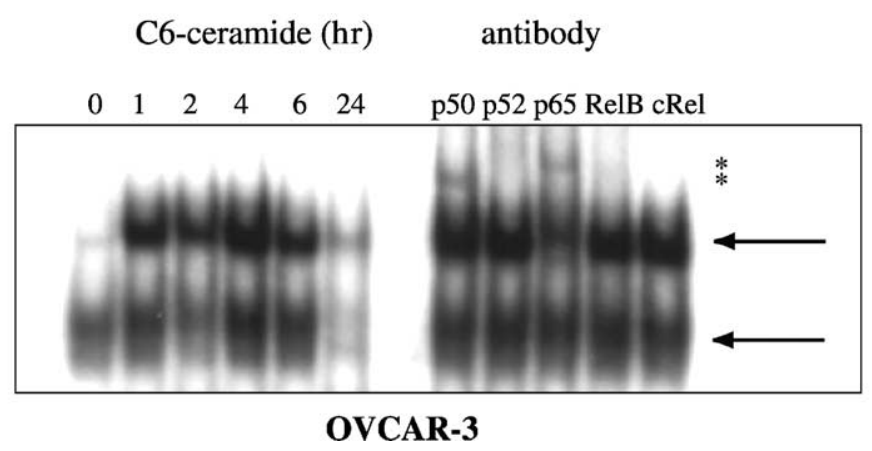

Fig. 1. NF-kB activation by ceramide. EMSAs were performed on nuclear proteins isolated from untreated and treated cells. (A) OVCAR-3 cells were treated with $\mathrm{C} 2$-ceramide $(50 \mu \mathrm{M})$ for 1, 2, 4, and $6 \mathrm{hr}$, and then a supershifting experiment was performed after a 1-hr ceramide treatment. OVCAR-3-MT cells were treated with $\mathrm{C} 2$-ceramide $(50 \mu \mathrm{M})$ for $30 \mathrm{~min}$ and $1 \mathrm{hr}$. (B) OVCAR-3 cells were treated with C6-ceramide $(50 \mu \mathrm{M})$ for $1,2,4,6$, and $24 \mathrm{hr}$, and then a supershifting experiment was performed after $1 \mathrm{hr}$ of ceramide treatment. The upper arrow indicates the specific NF- $\mathrm{BB}$ complex p50/p65, and the lower arrow indicates the specific NF- $\mathrm{BB}$ complex p50/p50. Supershifted complexes are marked with an asterisk. All the experiments were performed in triplicate.

cells (data not shown), as demonstrated by EMSA performed with nuclear extracts. The increase in NF- $\kappa B$ DNA-binding activity was observed within $1 \mathrm{hr}$ and persisted for $6 \mathrm{hr}$. NF- $\mathrm{KB}$ induction by $\mathrm{C} 2$-ceramides was

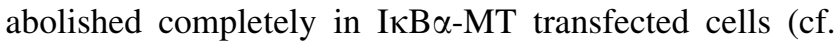
Fig. 1A). C16-ceramide did not show any activation of NF$\kappa \mathrm{B}$ (data not shown).

Supershift experiments after treatment with ceramide for $1 \mathrm{hr}$ were performed with antibodies directed against $\mathrm{NF}-\kappa \mathrm{B}$ proteins and demonstrated that the upper band was displaced by both p50 and p65 antibodies and was formed mainly of p50/p65 heterodimers (Fig. 1A and B; upper arrow). The lower band reacted only with p50 antibodies and likely corresponded to p50 homodimers (Fig. 1A and B; lower arrow).

\subsection{Cytotoxicity of ceramide in cancer cell lines}

To determine whether stable inhibition of the NF- $\kappa B$ transcription factor could increase the cytotoxic effect of ceramide, control and mutated I I B $\alpha$ HCT116 and OVCAR-3 cells were incubated in the presence of increasing C2-, C6- and C16-ceramide concentrations, and cell viability was measured after 24 and $48 \mathrm{hr}$ (Fig. 2A and B). Cell viability decreased in a concentration- and timedependent manner after $\mathrm{C} 2$ - and C6-ceramide treatment. C6-ceramide seemed to be somewhat more toxic than $\mathrm{C} 2$ - ceramide (Fig. 2A). C16-ceramide, on the other hand, did not influence cell viability (Fig. 2A). This could be due to its long carbon chain that prevents cellular uptake. This result has been confirmed by flow cytometry using the Annexin V/propidium iodide staining procedure (data not shown).

As shown in Fig. 2B, I $\kappa \mathrm{B} \alpha$ mutant-transfected OVCAR3 cells exhibited a cytotoxicity to C6-ceramide similar to that of the control cells. No statistically significant differences were found (unpaired $t$-test; $P>0.05$ ).

Under these conditions, NF- $\mathrm{BB}$ inhibition did not modify the cytotoxicity induced by either C6- or C2-ceramide (data not shown).

\subsection{Role of $N F-\kappa B$ in clonogenic survival after ceramide treatment}

To determine cell resistance to long-term ceramide treatment and clonogenic survival of cells harboring wild-type or mutated $\mathrm{I} \kappa \mathrm{B} \alpha$, we treated HCT116, HCT116-MT, OVCAR-3, and OVCAR-3-MT cells with C6-ceramide at different concentrations $(10,25$, and $50 \mu \mathrm{M})$ for $48 \mathrm{hr}$ and then incubated them with fresh medium for 12 days. Under these conditions, no difference was observed in the number and the size of the colonies between control cells and cells expressing mutated I $\mathrm{K} \mathrm{B} \alpha$ (data not shown). 

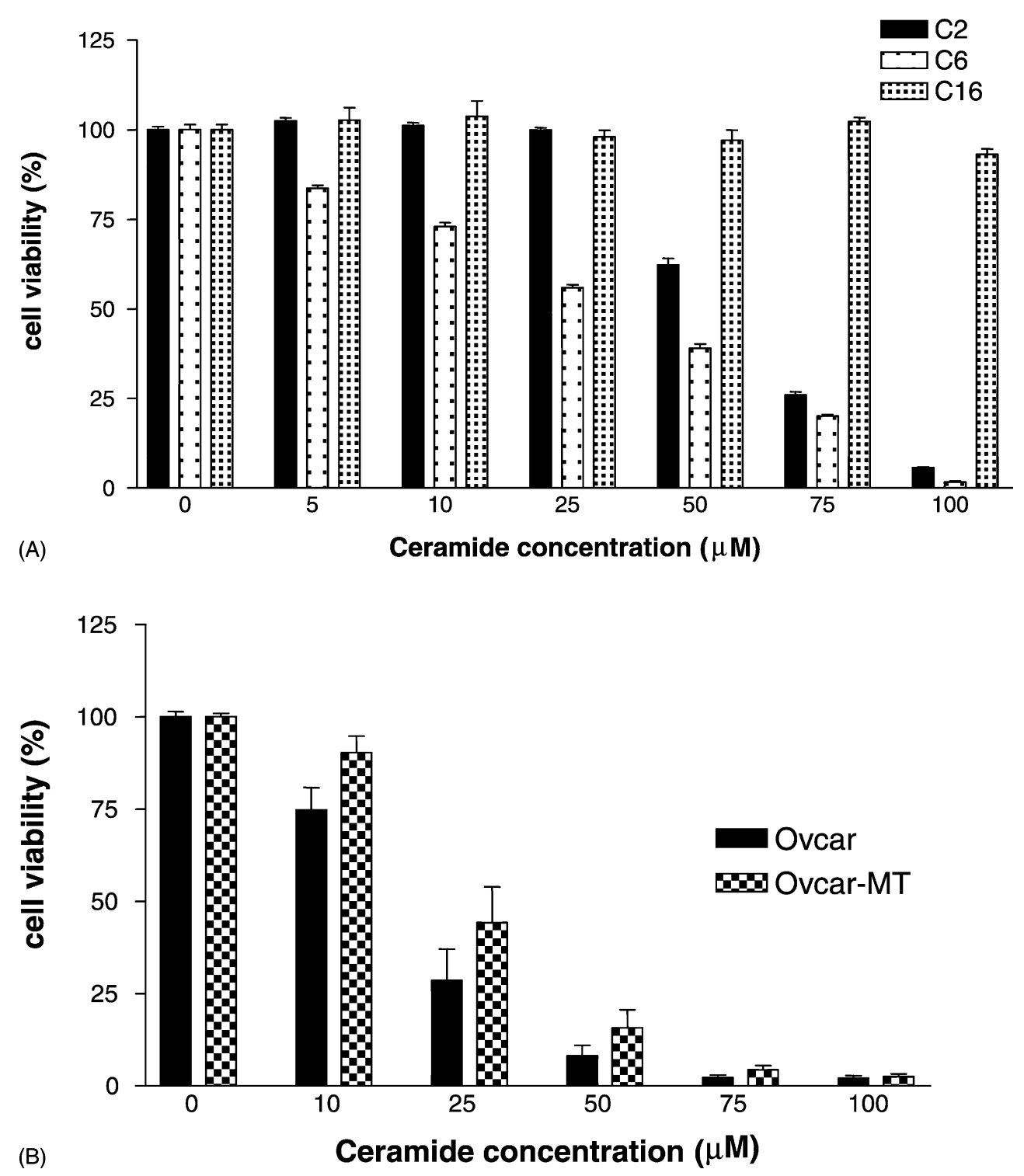

Fig. 2. Cell toxicity of ceramide. (A) HCT116 cells were seeded in 96-well plates at a concentration of 104/well and treated with C2-, C6-, or C16-ceramide at different concentrations $(5,10,25,50,75$, and $100 \mu \mathrm{M})$ or with control medium for $24 \mathrm{hr}$. Cell viability was estimated with the colorimetric WST- 1 test. The data are means $\pm \mathrm{SD}(\mathrm{N}=3)$. (B) OVCAR and OVCAR-MT cells were seeded in 96-well plates at a concentration of $10^{4} /$ well and treated with C6-ceramide at different concentrations $(10,25,50,75$, and $100 \mu \mathrm{M})$ or with control medium for $48 \mathrm{hr}$. Cell viability was estimated with the colorimetric WST-1 test. The data are means $\pm \mathrm{SD}(\mathrm{N}=12)$. No statistically significant differences were found between OVCAR and OVCAR-MT cells (unpaired $t$-test; $P>0.05$ ).

\subsection{Role of ceramide in cell death}

To investigate the nature of cell death (necrosis or apoptosis) induced by ceramide, HCT116 and HCT116MT cells were treated with $50 \mu \mathrm{M}$ C6-ceramide for various times (4, 7, 16, and $24 \mathrm{hr}$ ) and then analyzed by flow cytometry using the Annexin V/propidium iodide staining procedure (Fig. 3A and B).

A kinetic chart showing the time on the $x$-axis and the percentage $( \pm \mathrm{SD})$ on the $y$-axis for the Annexin $\mathrm{V}+$ $(\mathrm{AnV}+)$, the propidium iodide $(\mathrm{PI}+)$, and the doublepositive populations (Fig. 3) demonstrated that the $\mathrm{AnV}+$ population first increased and then emptied into the $\mathrm{AnV}+\mathrm{I}$ $\mathrm{PI}+$ population. This confirms that apoptosis ends in a secondary necrosis. The PI + population only appeared later and was constituted of isolated nuclei (data not shown). As shown in Fig. 3, the percentage of apoptotic HCT 116 cells increased to $10 \%$ after $7 \mathrm{hr}$ of treatment with C6-ceramide, and the necrotic cell rate reached $10 \%$ after $24 \mathrm{hr}$ of treatment. After $48 \mathrm{hr}$, most of the cells were dead and were stained by both propidium iodide and Annexin V (data not shown). No statistically significant differences were found (unpaired $t$-test; $P>0.05$ ) between apoptosis and necrosis in HCT116 and HCT116 IкB $\alpha$-MT cells.

\subsection{Caspase activation with ceramide-induced apoptosis}

Morphological apoptotic changes, such as nuclear condensation and fragmentation without membrane disrup- 

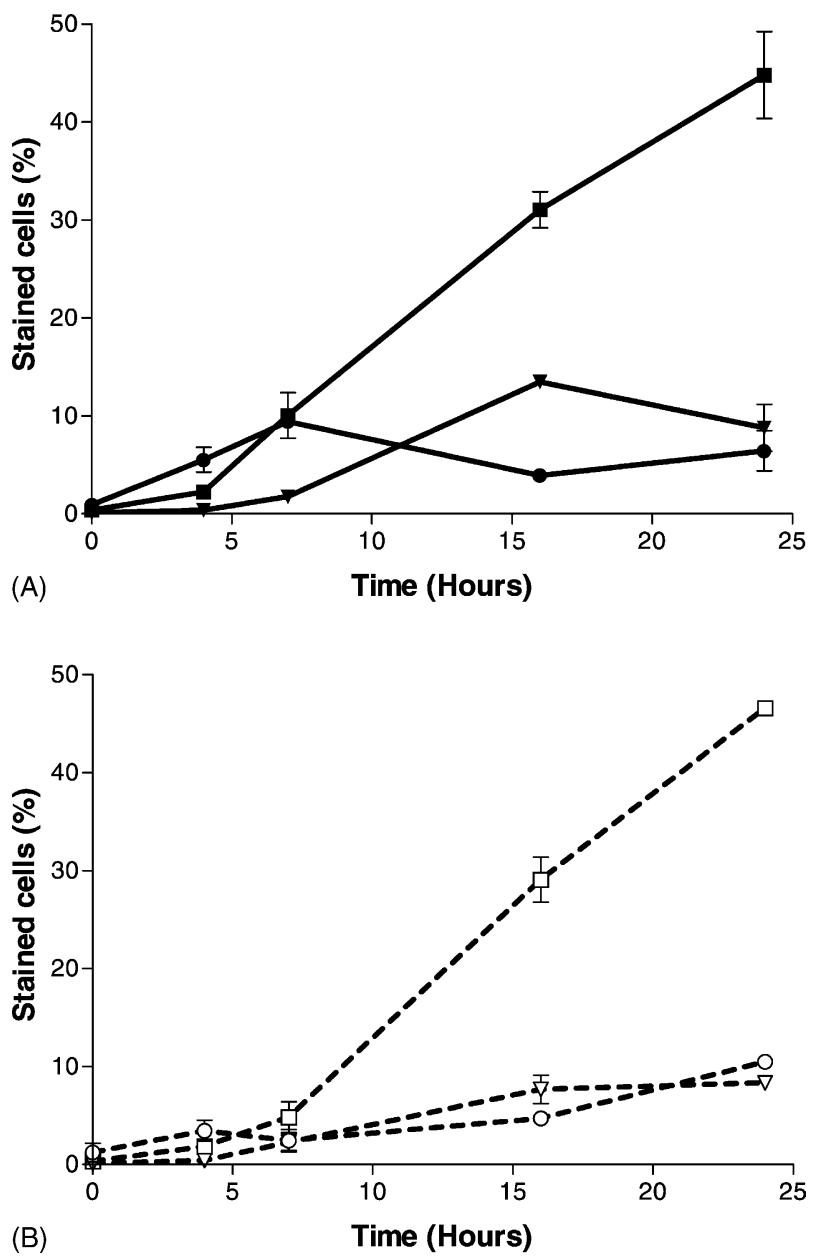

Fig. 3. Cell necrosis and cell apoptosis by C6-ceramide. (A) HCT116 cells were incubated with C6-ceramide $(50 \mu \mathrm{M})$ for $4,7,16$, and $24 \mathrm{hr}$. Cells were analyzed by flow cytometry with Annexin V (AnV) and propidium iodide (PI). All the experiments were performed in triplicate. Key: $(\boldsymbol{\square})$

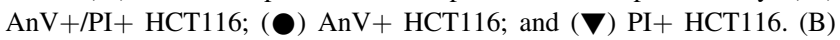
HCT116-MT cells were incubated with C6-ceramide $(50 \mu \mathrm{M})$ for $4,7,16$, and $24 \mathrm{hr}$. Cells were analyzed by flow cytometry with Annexin V (AnV) and propidium iodide (PI). All the experiments were performed in triplicate. Key: ( $\square$ ) AnV+/PI+ HCT116-MT; (O) AnV+ HCT116-MT; and $(\nabla)$ PI+ HCT116-MT. Values in both panels are presented as means $\pm \mathrm{SD}$.

tion, were observed under light microscopy after staining with DAPI. Moreover, TUNEL reaction labeled DNA strand breaks generated by apoptosis after only $6 \mathrm{hr}$ of ceramide treatment.

Apoptosis is frequently associated with activation of a family of cysteine aspartate proteases named caspases. To determine whether ceramide treatment led to caspase activation, caspase- 3 and caspase- 8 activities were analyzed in treated cells.

After treatment with C6-ceramide $(50 \mu \mathrm{M}, 24 \mathrm{hr})$, an activation of caspase- 3 (effector caspase) was observed in HCT116 cells (Fig. 4A and B) and in OVCAR-3 cells (data not shown). Caspase-3 activation was transient and the maximum peaks were obtained after $24 \mathrm{hr}$ of ceramide treatment. No significant differences in caspase-3 activa- tion were observed in control and I $\mathrm{B} \alpha$-mutated HCT116 cells (Fig. 4A and B). Ceramide treatment induced weak caspase-3 activation compared to daunomycin $(2 \mu \mathrm{M})$, which is a potent inducer of apoptosis in these cells [31].

Under the same experimental conditions, western blotting with anti-caspase- 8 antibody did not reveal any proteolytic processing of caspase-8 (initiator caspase) within $24 \mathrm{hr}$ of ceramide treatment (Fig. 5A).

To obtain additional evidence of caspase activation after ceramide treatment, cells were examined for the caspasedependent cleavage of PARP protein. PARP cleavage was detected by western blotting $30 \mathrm{hr}$ after exposure of cells to C6-ceramide, indicating the presence of functionally activated caspases (Fig. 5B).

\subsection{Increased cytochrome c release in ceramide-treated cells}

We investigated the participation of the mitochondria in ceramide-induced apoptosis by analysing the release of cytochrome $c$ from the mitochondria into the cytosol. Cytosolic, mitochondria-free extracts from HCT116 cells treated with $50 \mu \mathrm{M}$ C6-ceramide for 16 and $24 \mathrm{hr}$ showed an important release of cytochrome $c$ (Fig. 5C).

\subsection{Increased cell survival with caspase inhibitors}

HCT116 and HCT116-MT cells were pretreated for $1 \mathrm{hr}$ with the caspase inhibitor Z-VAD (cf. Fig. 6, condition 3) and the caspase-3 inhibitor (cf. Fig. 6, condition 4) and then were treated with C6-ceramide at $50 \mu \mathrm{M}$ for $24 \mathrm{hr}$ to examine the role of activated caspases in ceramide-induced cell death. The addition of the caspase inhibitors decreased cell death by only 5-10\%, which corresponds to the percentage of apoptosis after $24 \mathrm{hr}$ of treatment (cf. Fig. 3).

\subsection{Role of ceramide in cell cycle arrest}

After $16 \mathrm{hr}$ of C6-ceramide treatment, the DNA content was analysed by flow cytometry. The percentage of HCT116 cells in G0/G1 did not change significantly (41-45\%) (Fig. 7A and B). The percentage of cells in S phase decreased from 43 to $14 \%$, and the percentage of cells in G2/M increased from 16 to $42 \%$. That can be interpreted as a double block in G1 and G2, thus emptying the $\mathrm{S}$ phase.

\section{Discussion}

Among the recognized bioactive molecules, sphingolipid metabolites play important roles in signal transduction and cell regulation [2,22]. A number of extracellular agents, such as TNF- $\alpha$, and chemotherapeutic agents activate sphingomyelinase, which generates ceramides from membrane sphingomyelin. Ceramides were first shown to 
(A) C6-ceramide (hr)

C6-ceramide (hr)
0
16
$24 \quad 30$
40
$\begin{array}{llllll}0 & 6 & 16 & 24 & 30 & 40\end{array}$

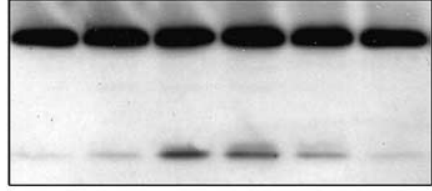

HCT116

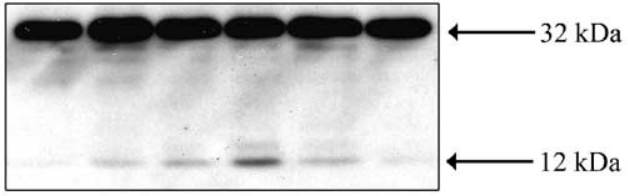

HCT116-MT

(B)

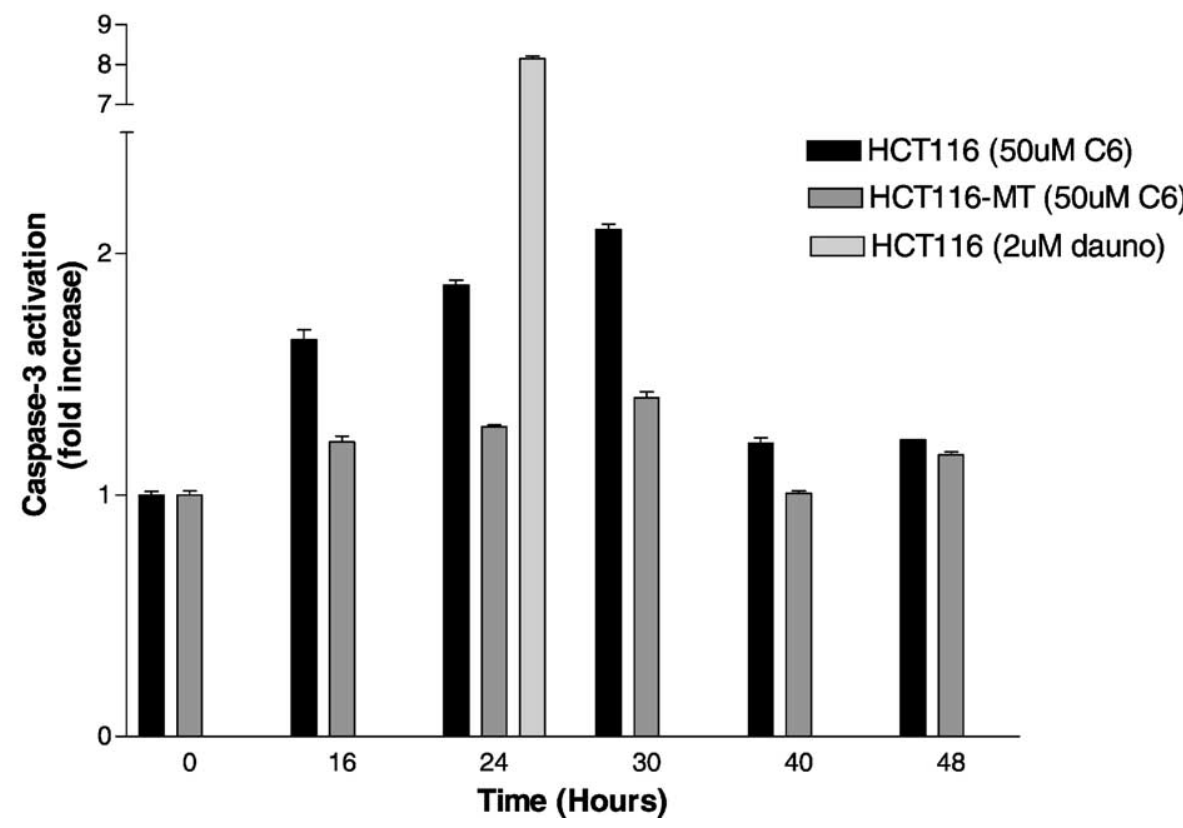

Fig. 4. Caspase-3 activation by ceramide. (A) HCT116 and HCT116-MT cells were treated with C6-ceramide (50 $\mu$ M) for different times $(6,16,24,30$, and $40 \mathrm{hr}$ ) or with control medium. Twenty micrograms of total cell lysates was separated on SDS-polyacrylamide gels, and immunoblotting was revealed with an anti-caspase-3 antibody. The intact 32-kDa pro-caspase-3 and its 12-kDa cleavage product are shown. The experiments were performed in triplicate. (B) Caspase- 3 activity was also determined by a caspase- 3 activity assay [the amount of release fluorescent product (coumarin) measuring emission at $460 \mathrm{~nm}$ with $380 \mathrm{~nm}$ excitation]. HCT116 and HCT116-MT cells were treated with C6-ceramide $(50 \mu \mathrm{M})$ for different times $(16,24,30,40$, and $48 \mathrm{hr})$ or with control medium. HCT116 cells treated with daunomycin $(2 \mu \mathrm{M})$ for $24 \mathrm{hr}$ were used as a positive control. Values are means \pm SD; this experiment was performed in triplicate.

be involved in cellular differentiation or cell cycle arrest [5]. But, recently, ceramides were postulated to be second messengers of apoptosis in some cell types [10]. The outcome of ceramide signaling is cell-type dependent. With respect to apoptosis, the activation of caspases is interesting to study since these proteases are actively involved in the execution phase of the apoptotic process. However, it is not clear whether activation of this protease family is dependent upon ceramide generation.

In our study, we showed that treatment of HCT116 and OVCAR-3 cancer cells with exogenous C2- and C6-ceramides led to NF- $\kappa \mathrm{B}$ activation, partial caspase-3 activation, and partial PARP cleavage. The caspase- 3 activation was transient, and the maximum peaks were obtained after $24 \mathrm{hr}$ of ceramide treatment. This observation was confirmed by caspase-dependent cleavage of PARP protein that was detected $30 \mathrm{hr}$ after ceramide treatment. More- over, the use of caspase inhibitors did increase cell viability by $10-20 \%$, confirming that caspase activation plays some role in ceramide-induced apoptosis.

An increase of cytochrome $c$ release into the cytoplasm was observed in the HCT116 cells after ceramide treatment. This suggests the participation of mitochondria in ceramide-induced apoptosis. In our study, apoptosis was also confirmed by flow cytometric analysis and cytochemical staining.

Exogenous C16-ceramide had no effect on cell viability and NF- $\kappa \mathrm{B}$ activation, probably due do its long fatty acid chain, which prevents its uptake into the cytoplasm. However, C16-ceramide is known to be an endogenous lipid species, and it would be very interesting to follow its variation after specific cell stresses using a very sensitive and selective technique, such as tandem mass spectrometry [32]. 
(A)

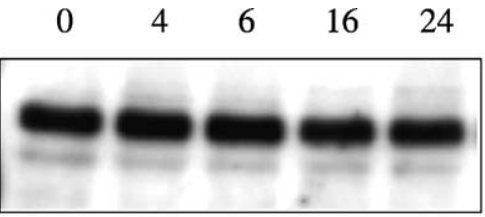

(B)

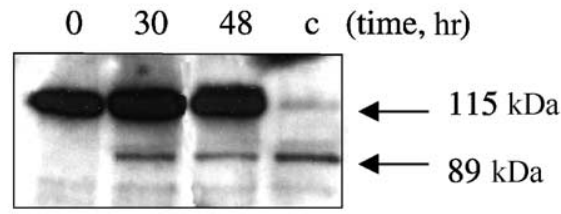

(C)

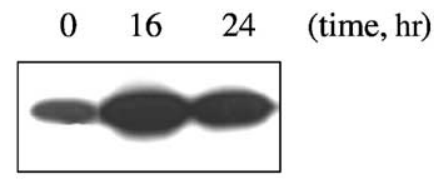

Fig. 5. (A) Lack of caspase-8 activation. HCT116 cells were untreated or treated with C6-ceramide $(50 \mu \mathrm{M})$ for $4,6,16$, and $24 \mathrm{hr}$. Twenty micrograms of total cell lysates was separated on SDS-polyacrylamide gels, and immunoblotting was revealed with an anti-caspase- 8 antibody. The intact $55-\mathrm{kDa}$ pro-caspase- 8 and its $40-\mathrm{kDa}$ cleavage product are shown. (B) PARP cleavage. HCT116 cells were untreated or treated with ceramide $(50 \mu \mathrm{M})$ for 30 and $48 \mathrm{hr}$. We also performed a positive control (c) with OVCAR-3-MT cells treated with TNF- $\alpha$ for $24 \mathrm{hr}$. Twenty micrograms of total cell lysates were separated on SDS-polyacrylamide gels, and immunoblotting was performed with an anti-PARP antibody. The intact $116-\mathrm{kDa}$ PARP and its $85-\mathrm{kDa}$ cleavage product are indicated. The arrow indicates the cleaved form of PARP. (C) Increase of cytochrome $c$ release. HCT116 cells were untreated or treated with ceramide $(50 \mu \mathrm{M})$ for 16 and $24 \mathrm{hr}$. Twenty micrograms of cytoplasmic extract was subjected to SDS-PAGE, and immunoblotting was performed with an anti-cytochrome $c$ antibody. All the experiments were performed in triplicate.
Several reports indicated that NF- $\kappa \mathrm{B}$ constitutive activity in cancer cells as well as NF- $\kappa \mathrm{B}$ activation by TNF- $\alpha$, anticancer drugs, or ionizing radiation could protect cells against apoptosis and would therefore favor cancer cell survival and resistance to chemotherapy, probably by controlling the expression of apoptosis inhibitors [24,30,33]. However, it is now recognized that NF-kB activity has a variable effect on cell mortality, depending on cell type, the stimulus, and the level of NF- $\kappa \mathrm{B}$ activity. Thus, it was interesting to determine the role of NF- $\mathrm{KB}$ in the toxicity of exogenous ceramides. For this investigation, we used cell lines expressing a mutated NF- $\kappa B$ inhibitor, which sequesters NF- $\kappa \mathrm{B}$ in the cytoplasm. Although TNF- $\alpha$ and ceramides could efficiently induce NF- $\kappa \mathrm{B}$ DNA-binding activity in control untransfected cells, NF- $\kappa \mathrm{B}$ inhibition did not increase the cytotoxic effect of $\mathrm{C} 2$ - and C6-ceramides. In our experimental conditions, NF- $\mathrm{KB}$ did not play a role in the ceramide apoptotic pathway, suggesting that other mechanisms are involved.

Conversely, it has been demonstrated that NF- $\mathrm{KB}$ activation can inhibit caspase activity through the transcription of the c-iap gene [34]. The activation of NF- $\kappa \mathrm{B}$ by ceramide treatment could explain why caspase activation is limited during ceramide-induced apoptosis. But this hypothesis does not seem to be confirmed by the experiments with cells expressing the mutated form of IкB $\alpha$.

Concerning cell cycle arrest, our results indicate that C6ceramide induced a double block in G1 and G2, thus emptying the $S$ phase. Other investigators reported a G1 or S phase cycle arrest after ceramide exposure [26]. This discrepancy supports growing evidence that significant cell-type-specific differences exist in cell death pathways.

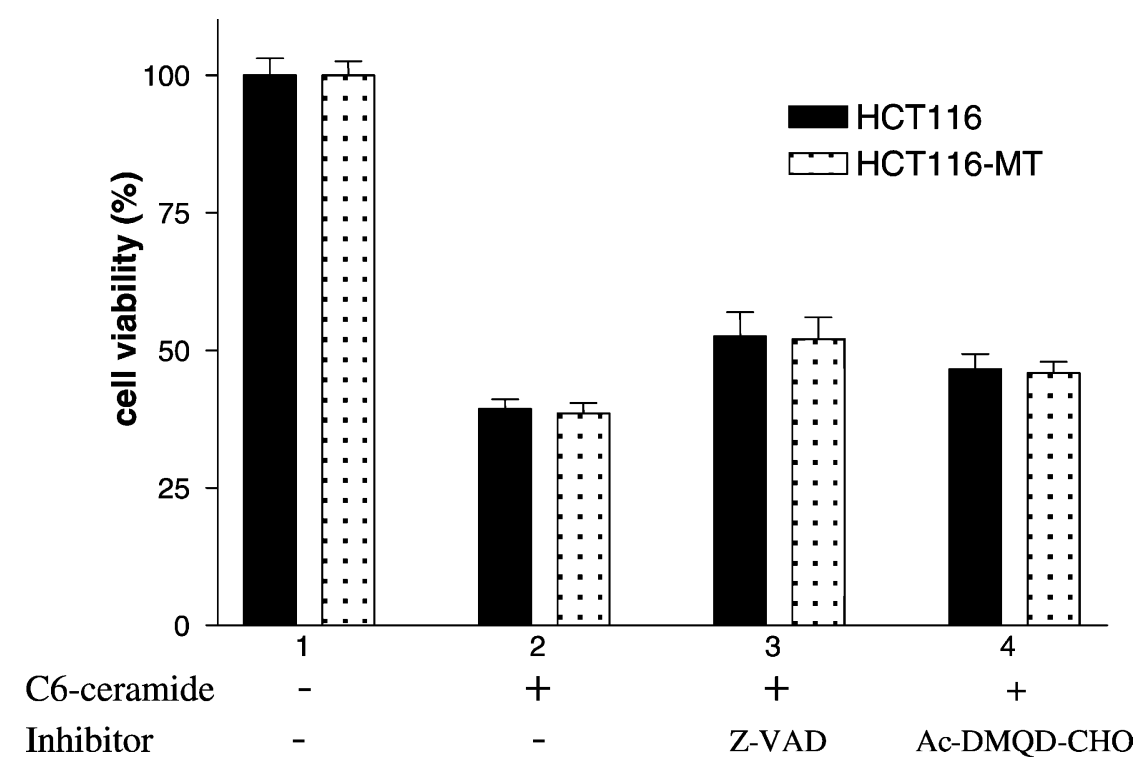

Fig. 6. Partial increase of cell survival with caspase inhibitors. HCT116 and HCT116-MT cells were seeded in 96-well plates at a concentration of $10^{4} /$ well and were not treated (1), treated with C6-ceramide at $50 \mu \mathrm{M}$ for $24 \mathrm{hr}$ (2), pretreated for $1 \mathrm{hr}$ with the caspase inhibitor Z-VAD and then treated with C6ceramide at $50 \mu \mathrm{M}$ for $24 \mathrm{hr}$ (3), or pretreated for $1 \mathrm{hr}$ with the caspase-3 inhibitor and then treated with C6-ceramide at $50 \mu \mathrm{M}$ for $24 \mathrm{hr}$ (4). Cell viability was estimated with the colorimetric WST-1 test. The data are means $\pm \mathrm{SD}(\mathrm{N}=3)$. 

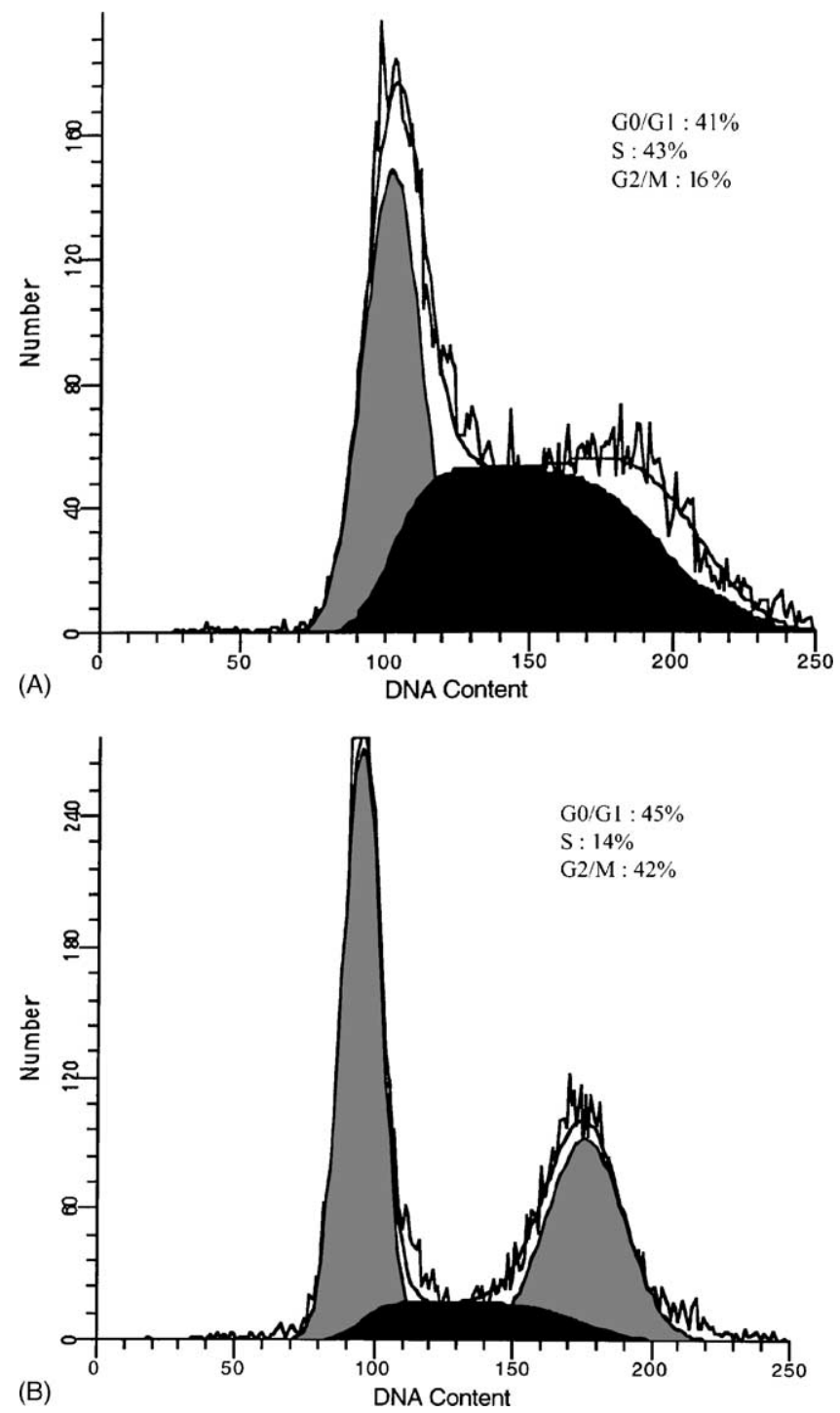

Fig. 7. G2/M cycle arrest. HCT116 cells were incubated with C6ceramide $(50 \mu \mathrm{M})$ for $16 \mathrm{hr}$. Cells were collected for propidium iodide staining, and DNA contents were analysed by flow cytometry. One of two independent experiments is shown. (A) Control cells. (B) Cells treated for $16 \mathrm{hr}$.

An improved understanding of the role of ceramide in tumor cell drug responses may facilitate the development of novel strategies for new or established chemotherapeutic agents. Indeed, in the treatment of cancer, suppression of anti-apoptotic signals may increase the sensitivity of target tissues to radiation or chemotherapy. Alternatively, activation of anti-apoptotic signals could prevent the inadvertent death of normal tissue. Moreover, it has become clear that tumor cells have developed strategies to reduce ceramide elevations and attenuate its pro-apoptotic effect.

\section{Acknowledgments}

We thank Sylvie Delhalle for the OVCAR-MT cells. M.F. is a Senior Research Assistant at the National Fund for Scientific Research (FNRS, Belgium). M.-P.M. is a Research Associate and J.P. is the Research Director at FNRS. We also thank the "Centre Anti-Cancéreux" (Liège, Belgium) and the National Fund for Scientific Research (FNRS) for their financial support.

\section{References}

[1] Gomez-Munoz A. Modulation of cell signaling by ceramides. Biochim Biophys Acta 1998;1391:92-109.

[2] Hannun YA. Function of ceramide in coordinating cellular responses to stress. Science 1996;272:1855-8.

[3] Pena LA, Fuks Z, Kolesnick R. Stress-induced apoptosis and the sphingomyelin pathway. Biochem Pharmacol 1997;53:615-21.

[4] Kolesnick RN, Goni FM, Alonso A. Compartmentalization of ceramide signaling: physical foundations and biological effects. J Cell Physiol 2000;184:285-300.

[5] Fishbein JD, Dobrowsky RT, Bielawska A, Garrett S, Hannun YA. Ceramide-mediated growth inhibition and CAPP are conserved in Saccharomyces cerevisiae. J Biol Chem 1993;268:9255-61.

[6] Venable ME, Lee YL, Smith MJ, Bielawska A, Obeid LM. Role of ceramide in senescence. J Biol Chem 1995;67:27-38.

[7] Belaud-Rotureau M-A, Lacombe F, Durrieu F, Vial J-P, Lacoste L, Bernard P, Belloc F. Ceramide-induced apoptosis occurs independently of caspases and is decreased by leupeptin. Cell Death Differ 1999;6:788-95.

[8] Bose R, Verheij M, Haimovitz FA, Scotto K, Fuks Z, Kolesnick R. Ceramide synthase mediates daunorubicin-induced apoptosis: an alternative mechanism for generating death signals. Cell 1995;82: 405-14.

[9] Gamard CJ, Dbaibo GS, Liu B, Obeid LM, Hannun YA. Selective involvement of ceramide in cytokine-induced apoptosis. Ceramide inhibits phorbol ester activation of nuclear factor $\mathrm{\kappa B}$. J Biol Chem 1997;272:16474-81.

[10] Noda S, Yoshimura S, Sawada M, Naganawa T, Iwama T, Nakashima $\mathrm{S}$, Sakai N. Role of ceramide during cisplatin-induced apoptosis in C6 glioma cells. J Neurooncol 2001;52:11-21.

[11] Obeid LM, Hannun YA. Ceramide: a stress signal and mediator of growth suppression and apoptosis. J Cell Biochem 1995;58:191-8.

[12] Okazaki T, Kondo T, Tashima M. Diversity and complexity of ceramide signaling in apoptosis. Cell Signal 1998;10:685-92.

[13] Ghahremani M, Foghi A, Dorrington JH. Activation of Fas ligand/ receptor system kills ovarian cancer cell lines by an apoptotic mechanism. Gynecol Oncol 1998;70:275-81.

[14] Selzner M, Bielawska A, Morse MA, Rudiger HA, Sindram D, Hannun YA, Clavien PA. Induction of apoptotic cell death and prevention of tumor growth by ceramide analogues in metastatic human colon cancer. Cancer Res 2001;61:1233-40.

[15] Verheij M, Bose R, Lin XH, Yao B, Jarvis WD, Grant S, Birrer MJ, Szabo E, Zon LI, Kyriakis JM, Haimovitz-Friedman A, Fuks Z, Kolesnick RN. Requirement for ceramide-initiated SAPK/JNK signaling in stress-induced apoptosis. Nature 1996;380:75-9.

[16] Chen CC, Sun YT, Chen JJ, Chang YJ. Tumor necrosis factor- $\alpha$ induced cyclooxygenase-2 expression via sequential activation of ceramide-dependent mitogen-activated protein kinases, and IкB kinase 1/2 in human alveolar epithelial cells. Mol Pharmacol 2001; 59:493-500.

[17] Gouaze V, Mirault ME, Carpentier S, Salvayre R, Levade T, AndrieuAradie N. Glutathione peroxidase-1 overexpression prevents ceramide production and partially inhibits apoptosis in doxorubicin-treated human breast carcinoma cells. Mol Pharmacol 2001;60:488-96.

[18] Hénaff M, Antoine S, Mercadier JJ, Coulombe A, Hatem SN. The voltage-independent B-type $\mathrm{Ca}^{2+}$ channel modulates apoptosis of cardiac myocytes. FASEB J 2002;16:99-101. 
[19] Siskind LJ, Colombini M. The lipids C2- and C16-ceramide form large stable channels. J Biol Chem 2000;8:38640-4.

[20] Kim HJ, Mun JY, Chun YJ, Choi KH, Kim MY. Bax-dependent apoptosis induced by ceramide in HL-60 cells. FEBS Lett 2001;505:264-8.

[21] Tepper AD, de Vries E, van Blitterswijk WJ, Borst J. Ordering of ceramide formation, caspase activation, and mitochondrial changes during CD95- and DNA damage-induced apoptosis. J Clin Invest 1999;103:971-8.

[22] Lavie Y, Cao H, Volner A, Lucci A, Han T, Geffen V, Giuliano AE, Cabot MC. Agents that reverse multidrug resistance, tamoxifen, verapamil, and cyclosporin A, block glycosphingolipid metabolism by inhibiting ceramide glycosylation in human cancer cells. J Biol Chem 1997;272:1682-7.

[23] Bonizzi G, Piette J, Merville MP, Bours V. Distinct signal transduction pathways mediate nuclear factor- $\mathrm{\kappa B}$ induction by IL- $1 \beta$ in epithelial and lymphoid cells. J Immunol 1997;159:5264-72.

[24] Bours V, Bentires-Alj M, Hellin AC, Viatour P, Robe P, Delhalle S, Benoit V, Merville MP. Nuclear factor- $\mathrm{\kappa B}$, cancer, and apoptosis. Biochem Pharmacol 2000;60:1085-90.

[25] Ryan KM, Ernst MK, Rice NR, Vousden KH. Role of NF-кB in p53-mediated programmed cell death. Nature 2000;404:8927.

[26] Jayadev S, Liu B, Bielawska AE, Lee JY, Nazaire F, Pushkareva MYu, Obeid LM, Hannun YA. Role for ceramide in cell cycle arrest. J Biol Chem 1995;270:2047-52.
[27] Hellin AC, Calmant P, Gielen J, Bours V, Merville MP. Nuclear factor$\kappa \mathrm{B}$-dependent regulation of $\mathrm{p} 53$ gene expression induced by daunomycin genotoxic drug. Oncogene 1998;16:1187-95.

[28] Bonizzi G, Dejardin E, Piret B, Piette J, Merville MP, Bours V. Interleukin- $1 \beta$ induces nuclear factor $\kappa \mathrm{B}$ in epithelial cells independently of the production of reactive oxygen intermediates. Eur $\mathrm{J}$ Biochem 1996;242:544-9.

[29] Brown K, Gerstberger S, Carlson L, Franzoso G, Siebenlist U. Control of I $\mathrm{I} B-\alpha$ proteolysis by site-specific, signal-induced phosphorylation. Science 1995;267:1485-8.

[30] Bentires-Alj M, Hellin AC, Ameyar M, Chouaib S, Merville MP, Bours V. Stable inhibition of nuclear factor $\mathrm{\kappa B}$ in cancer cells does not increase sensitivity to cytotoxic drugs. Cancer Res 1999;59:811-5.

[31] Hellin AC, Bentires-Alj M, Verlaet M, Benoit V, Gielen J, Bours V, Merville MP. Roles of nuclear factor- $\kappa \mathrm{B}$, p53, and p21/WAF1 in daunomycin-induced cell cycle arrest and apoptosis. J Pharmacol Exp Ther 2000;295:870-8.

[32] Fillet M, Van Heugen JC, Servais AC, De Graeve J, Crommen J. Separation, identification and quantification of ceramides in human cancer cells by liquid chromatography-electrospray ionization tandem mass spectrometry. J Chromatogr A 2002;949:225-33.

[33] Barkett M, Gilmore TD. Control of apoptosis by Rel/NK-кB transcription factors. Oncogene 1999;18:6910-24.

[34] Wang C-Y, Mayo MW, Korneluk RG, Goeddel DV, Baldwin Jr AS. NF- $\mathrm{KB}$ antiapoptosis: induction of TRAF1 and TRAF2 and c-IAP1 and c-IAP2 to suppress caspase-8 activation. Science 1998;281:1680-3. 